\title{
Konsep akuntansi pertanggungjawaban: perspektif filsafat kuno Tiongkok yin yang dan wu xing
}

\author{
Renna Magdalena ${ }^{1}$, Tjiptohadi Sawarjuwono ${ }^{2}$ \\ ${ }^{1}$ Universitas Pelita Harapan Surabaya, Jl. Ahmad Yani No. 288, Surabaya, Indonesia \\ ${ }^{2}$ Universitas Airlangga, Jl. Airlangga No. 4, Surabaya, Indonesia
}

Diterima: 7 Desember
2019
Direvisi: 31 Januari 2020
Disetujui: 30 Juni 2020
Koresponding:
Renna Magdalena
renna.magdalena@gmail
com
DOI:
http:/dx.doi.org/10.17977/
um004v7i22020p81

\section{Abstract}

The purpose of this paper is to propose the Responsibility Accounting concept that exists in Management Control System based on the perspective of the Chinese philosophy of $Y$ in $Y a n g$ and $W u X i n g$. Responsibility Accounting concept that has existed so far is a product of Western culture which is more focused on the achievements of each division as an individual Responsibility Center. As a result, the individual side of each division will grow and may weaken the unity of the organization. Responsibility Accounting concept may be improved if it can be integrated with the philosophy of $Y$ in $Y a n g$ and $W u$ Xing which does not only focus on achievement but also focuses on the contributions made by the one Responsibility Center to another. The result of this study is the concept of division's performance appraisal which is reflected in the Key Performance Indicator (KPI) which assess the division not only from the financial performance of its own division, but also from how the division transfers value to other divisions. From Wu Xing's philosophy, we obtain the direction of transfer of values among divisions as the Accountability Centers which is in accordance with the balance of each element. The Chinese Philosophy involved in this research is expected to provide a different view to the existing Responsibility Accounting concept and to encourage empathy in the organization which will enable companies to turn into sustainability and support Good Corporate Governance.

Keywords: Chinese Philosophy; Responsibility Accounting; Responsibility Centers; Yin Yang; Wu Xing

\begin{abstract}
Abstrak
Penelitian ini bertujuan untuk memperkenalkan konsep Akuntansi Pertanggungjawaban yang ada dalam Sistem Pengendalian Manajemen dari sudut pandang filosofi Tiongkok yaitu Yin Yang dan Wu Xing. Konsep Akuntansi Pertanggungjawaban yang ada selama ini merupakan produk dari budaya Barat yang lebih berfokus pada prestasi masing-masing divisi sebagai Pusat Pertanggungjawaban secara individu. Hal ini dapat memperkuat sisi individual dari tiap divisi namun juga dapat melemahkan persatuan organisasi. Konsep Akuntansi Pertanggungjawaban akan lebih berdaya guna jika dapat dipadukan dengan filosofi Yin Yang dan $W u$ Xing yang tidak hanya berfokus pada prestasi, tetapi juga berfokus pada kontribusi yang diberikan oleh Pusat Pertanggungjawaban satu kepada yang lain. Hasil dari penelitian ini adalah konsep penilaian kinerja yang tercermin dari Key Performance Indicator (KPI) yang digunakan untuk menilai divisi tidak hanya dari kinerja keuangan divisinya sendiri, tetapi juga dari bagaimana cara divisi tersebut memberi nilai bagi divisi lain. Dari filosofi $W u$ Xing, diperoleh arah transfer nilai antar divisi sebagai Pusat Pertanggungjawaban yang sesuai dengan keseimbangan masing-masing elemen. Penelitian yang memasukkan aspek filosofi Tiongkok ini diharapkan akan memberikan warna khusus pada konsep Akuntansi Pertanggungjawaban yang ada saat ini dan dapat mendorong empati dalam organisasi yang membawa perusahaan menuju keberlanjutan dan mendukung tata kelola perusahaan yang baik.

Kata Kunci: Filosofi Tiongkok; Akuntansi Pertanggungjawaban; Pusat Pertanggungjawaban; Yin Yang; Wu Xing
\end{abstract}

\section{PENDAHULUAN}

Penelitian ini menawarkan konsep Akuntansi Pertanggungjawaban dalam Sistem Pengendalian Manajemen dengan sudut pandang filsafat Tiongkok Yin Yang dan $W u$ Xing. Yin Yang dan Wu Xing adalah filsafat kehidupan kuno yang telah digunakan dalam berbagai aspek kehidupan termasuk di dalam dunia bisnis terutama di Asia Timur. Yin Yang dan Wu Xing merupakan nilai yang ada dalam gaya negosiasi di dunia bisnis China (Kommonen, 2011). Perusahaan dengan ideologi filosofi Yin Yang akan membentuk paradigma manajemen yang menggabungkan berbagai aturan dan sifat manusia

Cara mengutip: Magdalena, R., \& Sawarjuwono, T. (2020). Konsep akuntansi pertanggungjawaban: perspektif filsafat kuno Tiongkok yin yang dan wu xing. Jurnal Akuntansi Aktual. 7(2), 81-90. 
dengan tepat ke atmosfer bisnis yang bersifat kekeluargaan sehingga dapat memperolah manfaat ekonomi dan sosial yang baik serta memiliki kompetensi inti yang kuat (Li et al., 2011). Pauluzzo et al. (2018) berpendapat bahwa perusahaan dengan budaya barat perlu untuk mengadopsi filsafat $Y$ in Yang agar proses pembelajaran budaya di perusahaan yang multi budaya dapat berjalan dengan dinamis dan mampu mengelola dilema budaya dengan efektif. Penelitian mengenai perspektif Yin Yang di bidang Akuntansi pernah dilakukan oleh Evans et al. (2012) yang memuat diskusi mengenai penerapan Yin Yang dalam pendidikan profesi akuntan dan menghasilkan kesimpulan mengenai perlunya keseimbangan antara hard skill dan soft skill yang dimiliki oleh akuntan. Hancock et al. (2017) melakukan penelitian untuk mengetahui apakah ada keseimbangan (Yin Yang) antara kegiatan penelitian dan pengajaran yang dilakukan oleh para akademisi di bidang akuntansi dan keuangan di Australia dan New-Zealand yang menghasilkan kesimpulan bahwa akademisi junior lebih berorientasi pada kegiatan pengajaran dibandingkan dengan akademisi senior. Sampai dengan saat ini, masih belum banyak ditemukan literatur yang membahas penerapan filsafat $Y$ in $Y a n g$ dan $W u$ Xing dalam praktik akuntansi terutama dalam Sistem Pengendalian Manajemen yang merupakan salah satu topik Akuntansi Manajemen. Berdasarkan hal tersebut, konsep Akuntansi Pertanggungjawaban dengan pendekatan filosofi $Y$ in $Y$ ang dan $W u$ Xing diusulkan dalam penelitian ini.

Akuntansi Pertanggungjawaban merupakan bagian dari Sistem Pengendalian Manajemen yang bertujuan untuk mengarahkan divisi-divisi sebagai pusat pertanggungjawaban di dalam perusahaan untuk bergerak ke arah yang sama yaitu mencapai tujuan perusahaan. Menurut pandangan dunia barat, Akuntansi Pertanggungjawaban lebih berfokus pada hasil keuangan dimana setiap pusat pertanggungjawaban diberi tanggung jawab keuangan. Jika setiap pusat pertanggungjawaban berhasil mengelola tanggung jawabnya dengan baik, maka pimpinan dan anggota dari pusat pertanggungjawaban tersebut akan memperoleh reward yang setara dengan kinerja yang dihasilkan. Pandangan dunia barat mengenai Akuntansi Pertanggungjawaban menekankan pada kompetisi divisi sebagai satu individu dan berfokus pada hasil yang dicapai untuk mendukung tercapainya tujuan di dalam perusahaan. Berbeda dengan pandangan dunia bisnis barat, setiap aspek dalam filosofi Yin Yang memiliki dua sisi yaitu sisi positif dan sisi negatif dimana dua sisi tersebut saling melengkapi satu dengan yang lainnya. Sementara itu, semua elemen di perusahaan harus seimbang dalam filosofi Wu Xing. Perspektif filosofi Yin Yang dan Wu Xing dalam penelitian ini akan melengkapi konsep Akuntansi Pertanggungjawaban yang ada saat ini dengan sisi lain yang berbeda yaitu kerjasama yang diwujudkan dalam bentuk penilaian kinerja yang tidak hanya memuat transfer keuangan, tetapi juga transfer nilai berupa kontribusi suatu pusat pertanggungjawaban terhadap pusat pertanggungjawaban lainnya.

Keturunan Tiongkok yang berada di Cina Daratan maupun yang tersebar di seluruh dunia termasuk di Indonesia mempercayai filosofi Yin Yang sebagai suatu keseimbangan kutub positif dan kutub negatif yang terjadi secara terus menerus, serta merupakan sumber dari segala pergerakan dan kehidupan di dunia. Yang mengandung arti kelahiran atau siang hari yang mengandung energi positif dan Yin mengandung arti kematian atau malam hari yang mengandung energi negatif (Cooper, 1981). Sisi negatif dari Yin bukan berarti sesuatu yang bersifat inferior. Masing-masing energi positif (Yang) maupun negatif ( $Y$ in) tersebut memiliki sisi baik dan buruk (Wong, 1997). Sejalan dengan filosofi Yin Yang, keturunan Tiongkok juga mempercayai bahwa dunia (bumi) dibentuk melalui lima elemen yang dikenal dengan istilah $W u$ Xing. Kelima elemen tersebut adalah Kayu (木), Api (火), Tanah (土), Logam (金) dan Air (水) (Law \& Kesti, 2014). Kelima elemen dasar tersebut memiliki hubungan timbal balik yang terdiri dari hubungan saling mendukung (menghasilkan) dan saling menghancurkan (mengontrol). Hubungan saling mendukung (menghasilkan) menunjukkan bahwa jika dua elemen disatukan, maka akan menghasilkan energi positif yang sangat kuat atau dapat dikatakan kedua elemen tersebut cocok karena saling mendukung satu sama lain. Selain hubungan saling mendukung, terdapat juga hubungan saling menghancurkan atau mengontrol yang berarti jika dua elemen bertemu, maka kedua elemen kurang cocok atau memberi efek yang negatif. Filsafat hubungan "saling menghasilkan" dan "saling menghancurkan" dalam Wu Xing menunjukkan bahwa tidak terdapat satu elemen yang paling kuat atau paling lemah (Law \& Kesti, 2014). Sama halnya dengan konsep Yin dan $Y a n g$ dimana elemen-elemen tersebut memiliki ketergantungan satu sama lain dan dihubungkan oleh mata rantai kehidupan yang membawa eksistensi masing-masing. Dua filosofi kuno ini dapat dipakai bersamaan dan disebut dengan $Y$ in $Y a n g$. Wu Xing.

Yin Yang berbicara tentang keseimbangan dalam organisasi, sedangkan $\mathrm{Wu} X i n g$ berbicara mengenai ketergantungan lima elemen yang dapat diaplikasikan dalam divisi-divisi di suatu organisasi. Suatu organisasi pasti memiliki pengelompokan kegiatan serta pengaturan orang dan sumber daya lainnya. Perusahaan sebagai suatu organisasi juga memerlukan adanya spesialisasi pekerjaan, penyampaian laporan, dan saluran perintah (Robbins \& Judge, 2013). Masing-masing 
unit kerja atau komponen di dalam organisasi saling berhubungan dan memiliki ketergantungan. Jika unit kerja atau komponen tersebut memiliki kinerja yang baik, maka akan berpengaruh juga terhadap kinerja unit kerja atau komponen lainnya dan kinerja keseluruhan organisasi. Dalam disiplin akuntansi, terdapat konsep Akuntansi Pertanggungjawaban yang diimplementasikan dalam kerangka unit kerja atau divisi sebagai Pusat Pertanggungjawaban (Hansen et al., 2016). Implementasi Pusat Pertanggungjawaban berasumsi bahwa setiap unit kerja/divisi dalam organisasi harus memiliki peran dan pertanggungjawaban terkait dengan kinerja keuangan (Horngren et al., 2012). Sebagai contoh, Divisi Operasi harus bertanggung jawab penuh atas biaya untuk mengubah bahan baku menjadi produk jadi karena memiliki fungsi sebagai pusat biaya. Semakin efisien biaya yang dikeluarkan dalam satu periode keuangan, maka kinerja Divisi Operasi akan dinilai semakin baik. Hal yang sama juga terjadi dengan pusat-pusat keuangan lain seperti pusat pendapatan, pusat biaya, pusat laba, dan pusat investasi. Tujuan Pusat Pertanggungjawaban adalah sebagai basis perencanaan, pengendalian, dan penilaian kinerja oleh manajer atas unit organisasi yang dipimpinnya untuk memudahkan dalam mencapai tujuan organisasi, memfasilitasi terbentuknya keselaransan tujuan (Goal Congruence), mendorong kreativitas, dan daya inovasi bawahan serta sebagai alat pengendalian anggaran (Merchant \& Van der Stede, 2007). Setiap periode para pimpinan Pusat Pertanggungjawaban wajib menyusun laporan pertanggungjawaban atas kinerja divisi dan diserahkan kepada jenjang manajemen yang lebih tinggi. Laporan ini memuat Key Performance Indicator (KPI) atau Indikator Kinerja Utama (IKU) yang berorientasi keuangan sesuai dengan jenis dari Pusat Pertanggungjawaban yang terdiri dari pusat pendapatan, pusat biaya, pusat laba, dan pusat investasi. Sistem akuntansi pertanggungjawaban ini yang akan dipakai sebagai dasar untuk menilai prestasi masing-masing Pusat Pertanggungjawaban.

Setiap hal yang ada di dunia ini memiliki dua sisi yaitu baik dan buruk seperti pada filsafat $Y$ in dan Yang, kondisi yang sama juga terjadi dengan Pusat Pertanggungjawaban. Selain sisi baik dari pembentukan kerangka Pusat Pertanggungjawaban, terdapat permasalahan yaitu masing-masing unit kerja/divisi memiliki pertanggungjawaban sendiri sehingga akan terdapat kondisi dimana unit kerja yang merasa kurang mendapat dukungan atau bahkan tidak mendapat dukungan dari unit kerja lain di dalam satu perusahaan. Disamping itu, terdapat divisi yang merasa bawa divisi lain tidak cukup peduli pada divisi lainnya, sementara divisi tersebut sangat disiplin dan bekerja sepenuhnya untuk kepentingan divisinya sendiri. Masing-masing unit kerja/divisi dinilai berdasarkan peran dan kinerja keuangan dari masing-masing unit kerja/divisi, sehingga sangat wajar jika akhirnya masing-masing divisi lebih memikirkan kinerja sendiri dan tidak memikirkan kinerja divisi lain. Jika hal ini dibiarkan dan tidak dicari solusi atas permasalahan tersebut, maka Pusat Pertanggungjawaban akan menuju pada perpecahan di dalam organisasi. Masing-masing divisi akan berusaha menyelamatkan divisi masingmasing tanpa memedulikan divisi lain. Pemimpin dari masing-masing divisi ingin tampil paling baik di depan pemilik demi mendapatkan penilaian kinerja tertinggi. Perusahaan akan terpecah belah, terjebak pada konflik kepentingan terus-menerus, kehilangan fokus pada tujuan perusahaan, dan "rusak" dari dalam padahal persatuan tujuan adalah kunci utama bagi keberhasilan organisasi. Oleh karena itu, perusahaan harus memiliki tatanan organisasi yang saling bekerja sama dan memikirkan nasib bersama (bukan pribadi divisi). Sehubungan dengan kondisi tersebut, maka dibutuhkan Akuntansi Pertanggungjawaban yang juga dapat mengatasi masalah perpecahan di dalam organisasi. Alternatif yang diusulkan adalah konsep Akuntansi Pertanggungjawaban dengan perspektif filosofi Yin Yang dan Wu Xing.

Penelitian ini berfokus pada pentingnya memaknai perbedaan antar divisi sebagai pemersatu dan bukan sebagai pemecah belah. Penelitian ini juga menekankan pada pentingnya setiap divisi untuk menyadari bahwa setiap divisi tidak dapat berdiri sendiri walaupun setiap divisi memiliki fungsi yang berbeda. Filsafat hubungan "saling menghasilkan "dan "saling menghancurkan" dalam Wu Xing menunjukkan bahwa tidak terdapat satu elemen yang paling kuat atau paling lemah. Hal tersebut sesuai dengan dengan konsep Yin dan Yang dimana elemen-elemen tersebut memiliki ketergantungan satu sama lain dan dihubungkan oleh mata rantai kehidupan yang membawa eksistensi masing-masing. Sehubungan dengan itu, maka tulisan ini mengusulkan perpaduan konsep Akuntansi Pertanggungjawaban pada implementasi Pusat Pertanggungjawaban dengan perspektif filosofi Yin Yang dan $W u$ Xing agar dapat berdaya guna. Selanjutnya, ketika sebuah organisasi ingin mencegah terjadinya perpecahan dan mengambil manfaat maksimal dari implementasi Pusat Pertanggungjawaban, filosofi Yin Yang dan Wu Xing dalam Key Performance Indicator (KPI) perlu dimasukkan sebagai penilaian kinerja masing-masing divisi. Filosofi Yin Yang digunakan untuk konsep penilaian kinerja divisi sebagai Pusat Pertanggungjawaban dengan KPI yang seimbang dan filosofi $W u$ Xing digunakan untuk menentukan arah dari "transfer nilai" satu divisi ke divisi lain. 


\section{METODE}

Penelitian ini adalah penelitian konseptual yang akan memberikan gagasan atau teori abstrak dan mengembangkan konsep baru atau menafsirkan ulang gagasan atau teori yang sudah ada. Penelitian konseptual berfokus pada konsep atau teori yang menjelaskan atau menggambarkan masalah atau fenomena yang sedang diteliti dan menjalin atau menghubungkan teori-teori terkait dengan fenomena yang sedang diteliti. Penelitian ini akan membandingkan konsep Akuntansi Pertanggungjawaban yang ada saat ini dan mengkonseptualisasikan konsep tersebut dalam filosofi $Y$ in Yang dan $W u$ Xing serta memberikan argumentasi terkait alasan penggunaan filosofi Yin Yang dan $\mathrm{Wu}$ Xing yang diperlukan demi menjaga harmonisasi antar divisi untuk mencapai tujuan perusahaan. Penelitian ini juga akan memberikan konsep penilaian kinerja divisi Pusat Pertanggungjawaban berdasarkan perspektif $Y$ in Yang dan Wu Xing untuk selanjutnya diwujudkan dalam Key Performance Indicator (KPI) atau Indikator Kinerja Unit (IKU).

\section{HASIL DAN PEMBAHASAN}

Artikel ini membahas Yin Yang sebagai konsep untuk mendorong persatuan dalam organisasi, aplikasi Yin Yang dalam penilaian kinerja Pusat Pertanggungjawaban, perspektif $W u$ Xing dalam menetapkan arah "transfer nilai" antar divisi, serta perspektif Yin Yang dan Wu Xing dalam Akuntansi Pertanggungjawaban.

\section{Yin Yang sebagai Konsep untuk Mendorong Persatuan dalam Organisasi}

Persatuan dalam organisasi sangat diperlukan agar visi dan misi di dalam organisasi dapat tercapai. Prinsip Sistem Pengendalian Manajemen menekankan bahwa keselarasan tujuan (Goal Congruence) merupakan fokus pengendalian yang utama. Keselarasan tujuan adalah bagaimana orang-orang di dalam perusahaan memiliki satu tujuan yang sama. Peran manajemen puncak di perusahaan lebih pada fungsi strategis dibandingkan dengan fungsi operasional dimana fungsi strategis tidak akan dapat berjalan dengan baik tanpa dukungan dari fungsi operasional. Di dalam struktur perusahaan, peran operasional lebih banyak dilakukan oleh manajer divisi yang menjadi Pusat Pertanggungjawaban. Peran manajemen puncak adalah memotivasi, mengarahkan, dan mengambil keputusan agar para manajer selaku pimpinan Pusat Pertanggungjawaban dapat melaksanakan tugas dengan baik untuk mencapai tujuan organisasi. Dalam perspektif dunia bisnis barat, para pimpinan Pusat Pertanggungjawaban lebih sering berkomunikasi masalah keuangan kepada manajemen puncak dibandingkan dengan operasional (Merchant \& Van der Stede, 2007). Perilaku kepemimpinan Yin memprioritaskan pendekatan "lembut", sedangkan kepemimpinan Yang dijiwai dengan energi kosmik maskulin yang memprioritaskan pendekatan "gigih dan kuat". Perilaku kepemimpinan Yin Yang adalah kombinasi dari gaya kuat dan lembut tergantung dari situasi dan kondisi yang dihadapi oleh pimpinan. Kepemimpinan Yin Yang menunjukkan pemimpin yang tidak kaku dan fleksibel tetapi tetap mengutamakan tujuan organisasi. Lee \& Reade (2018) menemukan bahwa kepemimpinan Yin Yang memiliki dampak positif terhadap komitmen karyawan.

Yin Yang adalah konsep kompleks dimana Yin dan Yang memiliki sifat yang berlawanan, tetapi juga saling melengkapi. Menurut Law \& Kesti (2014), Yin dan Yang membentuk siklus tertutup yang berada pada ujung yang berlawanan dari sebuah siklus. Dalam Akuntansi Pertanggungjawaban, hal ini dapat digambarkan dalam situasi divisi-divisi di dalam perusahaan yang memiliki fungsi dan tanggungjawab berbeda. Fungsi keuangan yang berbeda pada pusat biaya, pusat pendapatan, pusat laba, dan pusat investasi menyebabkan unit kerja/divisi terpisah satu sama lainnya. Yin Yang saling tergantung sehingga tidak ada yang sepenuhnya Yin atau sepenuhnya Yang. Yin menciptakan Yang dan Yang mengaktifkan Yin. Contoh ilustrasi tersebut adalah tidak ada siang tanpa malam dimana siklus menunjukkan ketika satu siang berakhir maka malam muncul dan setelah sepanjang malam terjadi maka siang akan datang lagi. Dalam Konsep Akuntansi Pertanggungjawaban dengan perspektif Yin Yang; tiap divisi harus memiliki paradigma bahwa setiap divisi tidak dapat berdiri sendiri. Divisi Pemasaran tidak dapat berdiri sendiri, begitu pula dengan Divisi Riset dan Pengembangan juga tidak dapat berdiri sendiri seperti halnya Yin Yang dimana ada hitam di dalam putih dan ada putih di dalam hitam. Yin dan Yang harus berimbang dan tingkat relatif Yin Yang terus berubah. Perubahan ini adalah perubahan yang harmonis, tetapi ketika Yin atau Yang tidak seimbang maka terdapat proses mempengaruhi satu sama lain dan terlalu banyak dari satu sisi pada akhirnya dapat melemahkan (mengkonsumsi) yang lain. Divisi di dalam perusahaan harus mendapat perhatian sesuai dengan porsi masing-masing yang mengacu pada strategi perusahaan. Strategi perusahaan yang pada akhirnya akan menentukan divisi mana yang menjadi divisi inti perusahaan dan divisi mana yang menjadi divisi pendukung dimana divisi utama dan divisi pendukung harus berimbang. Transformasi 
Yin dan Yang mengacu pada situasi bahwa seseorang dapat berubah menjadi yang lain, tetapi itu bukan peristiwa acak karena hanya terjadi ketika waktunya tepat. Sebagai contoh adalah musim semi hanya datang ketika musim dingin selesai. Sebelum tahun 2000, Divisi Sistem Informasi hanya menjadi divisi pendukung yang keberadaan divisi tersebut tertutupi oleh divisi lain yang secara nyata menghasilkan pemasukan keuangan bagi perusahaan. Kondisi saat ini terutama ketika memasuki tahun 2020 dimana pandemi Covid-19 menyebabkan perusahaan mengadopsi konsep Work from Home (WFH) yang mewajibkan karyawan bekerja di rumah. Dalam kondisi tersebut, peran sistem informasi menjadi penting karena hampir semua kegiatan perusahaan dilakukan secara online. Sistem informasi saat ini mendukung seluruh operasional perusahaan secara online. Contoh dari hasil kerja Divisi Sistem Informasi adalah seorang karyawan dapat mengendalikan komputer kantor dan melakukan pekerjaan seperti biasa dari rumah masing-masing.

Makna simbol Yin Yang bukan hanya berbicara pada perbedaan warna hitam dan putih, tetapi juga berbicara mengenai titik bulatan hitam yang ada di bagian putih dan titik bulatan putih yang ada di bagian hitam. Keberadaan dua bulatan tersebut menunjukkan bahwa Yin Yang bukan hanya tentang perbedaan hitam dan putih, tetapi juga menunjukkan bahwa bagian putih tidak akan sempurna tanpa adanya hitam dan demikian pula bagian hitam tidak akan sempurna dengan adanya putih. Setiap Pusat Pertanggungjawaban di dalam organisasi tidak akan sempurna tanpa adanya peran dari divisi lainnya. Divisi Pemasaran sebagai Pusat Pertanggungjawaban Pendapatan (Revenue Center) tidak akan dapat berfungsi dengan baik jika Divisi Operasi sebagai Pusat Pertanggungjawaban Biaya (Cost Center) tidak dapat menghasilkan produk yang baik dan layak jual. Hal ini menunjukkan dua fungsi yang bertentangan yaitu pendapatan dan biaya seperti halnya Yin Yang yang tidak dapat berdiri sendiri tetapi harus saling melengkapi agar masing-masing dapat berfungsi dengan baik. Divisi Operasi juga tidak akan dapat menghasilkan produk yang baik jika tidak didukung oleh Divisi Riset dan Pengembangan serta Divisi Keuangan. Suatu Pusat Pertanggungjawaban tidak dapat berdiri sendiri di dalam perusahaan. Oleh karena itu, penilaian masing-masing Pusat Pertanggungjawaban berdasarkan prestasi divisi secara individu seperti konsep Akuntansi Pertanggungjawaban dari budaya barat akan lebih baik jika dikolaborasikan dengan Yin Yang dan Wu Xing sebagai filosofi dalam mengelola Pusat Pertanggungjawaban.

\section{Aplikasi Yin Yang dalam Penilaian Kinerja Pusat Pertanggungjawaban}

Menurut perspektif Yin Yang seperti yang dibahas sebelumnya, sifat "egois" masing-masing divisi bukan hal yang salah dan bekerja keras bagi kepentingan divisi juga tidak salah. Namun, kondisi organisasi yang sempurna akan terjadi jika sifat individualisme masing-masing divisi seimbang dengan rasa kesatuan sebagai satu organisasi dan yang lebih utama adalah melihat kepentingan perusahaan secara keseluruhan. Bagaimana menumbuhkan keseimbangan Yin Yang dalam berbagai Pusat Pertanggungjawaban dalam organisasi? Prioritas utama adalah pada Key Performance Indicator (KPI) yang digunakan dalam penilaian kinerja di masing masing Pusat Pertanggungjawaban.

Penilaian kinerja tradisional hanya menilai kinerja masing-masing Pusat Pertanggungjawaban dengan faktor finansial yang memiliki proporsi dominan dan diikuti dengan sedikit faktor non-finansial. Dengan menggunakan perspektif Yin Yang, penilaian kinerja masing-masing Pusat Pertanggungjawaban tidak hanya dinilai dari kinerja diri sendiri baik dari segi finansial maupun non-finansial, tetapi dinilai juga dari bagaimana nilai (value) diberikan ke divisi lain. Pusat pertanggungjawaban tidak lagi memikirkan pusat pertanggungjawabannya terlebih dahulu, tetapi seimbang dengan kepentingan seluruh organisasi. Penelitian ini mengusulkan untuk memperbarui poin-poin KPI dalam penilaian kinerja sesuai dengan perspektif Yin Yang. Tabel 1 menunjukkan usulan komponen Yin Yang dalam KPI Pusat Pertanggungjawaban.

Konsep Yin mendorong divisi dalam perusahaan untuk memberikan yang terbaik berdasarkan kuantitas angka yaitu kinerja keuangan. Hal ini harus diseimbangkan dengan Yang dimana divisi dalam perusahaan tidak hanya dinilai dari angka, tetapi juga kualitas dari divisi itu sendiri. Kuantitas ( $Y$ in) berarti banyaknya pekerjaan yang dilakukan yang dalam hal ini KPI bisa jadi membuat divisi

Tabel 1. Komponen Key Performance Indicator (KPI)

\begin{tabular}{cc}
\hline Yin & Yang \\
\hline Kuantitas & Kualitas \\
Kompetisi & Kerjasama \\
Individual & Kesatuan \\
Merasakan secara fisik & Merasakan dengan hati \\
\hline
\end{tabular}


menyelesaikan pekerjaan sebanyak mungkin demi memenuhi target prestas divisi. Namun, fokus kepada kuantitas bisa menyebabkan hilangnya perhatian pada kualitas (Yang). Divisi Pemasaran memiliki KPI dimana salah satunya adalah jumlah penjualan. Jika Divisi Pemasaran hanya berfokus pada angka penjualan tanpa memastikan aspek lainnya seperti kepuasan pelanggan, kejujuran kepada pelanggan, kualitas produk yang ditawarkan dan hubungan jangka panjang dengan pelanggan, maka dapat dipastikan perusahaan akan kehilangan pelanggan. Jika hanya dinilai berdasarkan kuantitas, Divisi Persediaan akan berusaha mencari pemasok yang mampu menyediakan harga murah tetapi tidak memperhitungkan aspek lainnya seperti kualitas bahan baku, pengiriman tepat waktu, dan kemampuan pemasok dalam menyediakan barang dalam jangka panjang.

Konsep Yin mendukung divisi dalam organisasi untuk saling berkompetisi, tetapi sifat kompetisi tersebut harus diimbangi dengan kesadaran untuk bekerjasama (Yang). Penilaian Pusat Pertanggungjawaban berdasarkan prestasi masing-masing divisi tentu akan menimbulkan kompetisi di antara divisi-divisi sebagai Pusat Pertanggungjawaban. Kompetisi memiliki hal positif yaitu membuat divisi menjadi terpacu untuk menunjukkan bahwa divisi tersebut lebih baik daripada divisi lain, tetapi kompetisi antar divisi dapat menghilangkan potensi prestasi yang muncul dari kerjasama. Untuk proyek peluncuran suatu produk baru diperlukan kerjasama dari berbagai divisi (intraorganisasi). Divisi Pemasaran diperlukan untuk mengetahui preferensi konsumen dan kisaran harga yang konsumen bersedia keluarkan untuk membeli produk baru. Divisi Riset dan Pengembangan diperlukan untuk dapat mengembangkan produk baru yang sesuai dengan keinginan konsumen. Divisi Operasi diperlukan untuk dapat memproduksi produk secara massal yang didesain oleh Divisi Riset dan Pengembangan. Divisi Keuangan dapat melakukan penganggaran serta perhitungan biaya dan harga dari hasil Divisi Riset dan Pengembangan serta Divisi Operasi. Sementara itu, Divisi SDM memberikan dukungan dengan menyediakan SDM dan melatih SDM secara memadai.

Perspektif $Y$ in mendukung sifat individualisme dalam Akuntansi Pertanggungjawaban, tetapi harus diimbangi dengan kesadaran divisi sebagai bagian dari satu kesatuan organisasi. Penilaian Pusat Pertanggungjawaban sebagai satu individu dapat membuat divisi satu memandang divisi lain sebagai kompetitor daripada sebagai bagian dalam satu perusahaan. Penilaian kinerja Pusat Pertanggungjawaban secara individu memiliki hal yang positif yaitu adanya loyalitas pada divisi dan ingin memberikan usaha yang terbaik untuk divisi. Sisi negatif dari penilaian tersebut adalah pada rentannya kesatuan di dalam perusahaan. Oleh karena itu, diperlukan KPI yang memuat transfer nilai antar divisi sebagai prestasi yang diukur untuk penilaian kinerja.

Perspektif $Y$ in memandang perlu bagi divisi dalam organisasi untuk merasakan yang dapat dirasakan dan dilihat, tetapi perspektif Yang memandang perlu untuk merasakan dengan hati. Proses merasakan secara fisik lebih pada penghargaan dari penilaian kinerja karena secara fisik berarti berbicara mengenai uang/komisi/bonus (Yin). Proses merasakan secara hati berhubungan dengan rasa kebanggaan, rasa memiliki dan rasa sebagai bagian dari perusahaan (Yang). Hal ini harus tercermin juga di dalam KPI sehingga harus terdapat beberapa poin dalam KPI yang memberikan reward tidak secara fisik. Contohnya adalah dengan menampilkan foto anggota divisi yang berhasil mencapai prestasi tertentu. Penjualan terkadang tidak memenuhi target seperti pada situasi pandemi Covid-19 di sepanjang tahun 2020. Pada kondisi seperti wabah penyakit dapat menyebar seperti ini, pengukuran fisik tidak dapat digunakan karena perekonomian makro sedang jatuh. Hal ini menunjukkan bahwa tidak selalu besarnya angka (fisik) yang digunakan untuk melihat prestasi, tetapi hati dapat digunakan untuk memprediksi lingkungan eksternal bisnis serta menentukan target dan menilai kinerja suatu divisi.

Perspektif $Y$ in mendukung adanya penilaian secara eksplisit yang berarti dapat dilihat langsung pada saat ini atau dalam jangka pendek. Namun, perspektif $Y a n g$ memandang perlu juga untuk memberikan penilaian secara implisit yang memiliki dampak jangka panjang. Penilaian prestasi yang hanya melihat dari segi jangka pendek akan berdampak pada jangka panjang. Perpektif Yin mendorong divisi dalam perusahaan untuk terus berusaha yang terbaik dan mencapai kinerja maksimal saat ini, tetapi perspektif Yang lebih menekankan pada memelihara dan memiliki tujuan jangka panjang. Semua perspektif harus dapat dilakukan secara seimbang sehingga KPI yang digunakan bukan hanya berupa kinerja harian, mingguan, bulanan, atau tahunan, tetapi juga berupa apa yang dapat dihasilkan oleh divisi tersebut dalam waktu lama seperti lima sampai sepuluh tahun ke depan. Divisi Operasi dapat mengirimkan karyawan untuk magang di perusahaan luar negeri agar dapat menggunakan mesin terbaru dan menguasai teknologi terbaru agar produk yang dihasilkan dapat sesuai standar internasional. Kasus seperti ini tidak dapat langsung dinilai sebagai penurunan kinerja karena manfaat atas biaya yang dikeluarkan belum pasti dapat langsung didapatkan, tetapi manfaat ini akan diperoleh tahun depan saat mesin terbaru dan teknologi terbaru telah terpasang di perusahaan. 
Yin Yang dapat meminimalisasi asimetri informasi. Pada saat Yin dan Yang dalam keadaan seimbang, maka setiap Pusat Pertanggungjawaban akan memiliki kinerja yang baik. Sebaliknya, jika masing-masing Pusat Pertanggungjawaban tidak harmonis, maka kinerja satu perusahaan akan memburuk.

\section{Perspektif Wu Xing dalam Menetapkan Arah Transfer Nilai Antar Divisi}

Semua unsur di dalam dunia ini memiliki sifat dasar unsur alam bahkan manusia juga memiliki kemiripan dengan sifat-sifat dasar unsur-unsur alam. Contohnya adalah unsur kayu/pohon. Terdapat seseorang yang bisa diandalkan, menyokong banyak orang dan aktif seperti kayu/pohon yang selalu tumbuh. Demikian pula dengan sifat unit kerja/divisi di organisasi, Divisi Keuangan adalah unsur kayu karena mampu menyuplai seluruh divisi lain. Divisi Keuangan menyokong keuangan perusahaan agar dapat bertumbuh tinggi. Seluruh operasional di dalam perusahaan akan bergerak bergantung pada cara Divisi Keuangan mengelola dan mengalokasikan dana.

Key Performance Indicators (KPI) bukan lagi berorientasi pada kinerja divisi sendiri, tetapi pada seberapa besar nilai (value) yang telah diberikan divisi tersebut bagi divisi lain. Selain itu, KPI juga bukan lagi dinilai dari kinerja keuangan (Transfer Pricing) saja, tetapi seimbang dengan transfer nilai. Perspektif $W u$ Xing dalam artikel ini digunakan sebagai dasar untuk menentukan keterkaitan di antara Pusat Pertanggungjawaban. Masing-masing Pusat Pertanggungjawaban akan dianalisis dengan pandangan $\mathrm{Wu}$ Xing untuk mengindentifikasi kecocokan dan transfer nilai antar divisi. Masing-masing divisi akan diidentifikasi termasuk dalam elemen yang mana. Setelah mengetahui elemen alam suatu divisi, maka dapat diputuskan arah dari transfer nilai.

\section{Kayu/Pohon}

Kayu/pohon membentuk cabang-cabang dimana daun-daun terhubung. Sama halnya dengan kayu/ pohon, Divisi Keuangan bertanggungjawab untuk menyuplai dana bagi berbagai unit, departemen, dan tim di dalam organisasi. Fungsi utama dari batang pohon adalah untuk menumbuhkan dan memberikan nutrisi agar mendapatkan panen yang cukup. Divisi Keuangan harus dapat membagi dana dan membuat keputusan agar sumber daya perusahaan menghasilkan laba bagi perusahaan. Divisi Keuangan harus mampu beradaptasi dengan lingkungan sama seperti pohon yang sanggup beradaptasi dengan lingkungan. Divisi Keuangan mengelola sumber daya keuangan agar organisasi bertumbuh dan menghasilkan laba. Bagian dari laba dapat diberikan ke pemilik dan untuk membayar pajak, serta sebagian lagi dapat diinvestasikan untuk pertumbuhan di masa depan. Sesuai dengan sifat kayu/pohon yang ekspansif, pemecah masalah, dan mendominasi, maka sifat tersebut yang juga dimiliki oleh Divisi Keuangan di organisasi.

2. Api

Api menghasilkan panas dan energi yang akan membantu tanah untuk bertumbuh. Divisi Operasi dan Divisi Sumber Daya Manusia (SDM) dalam organisasi adalah api untuk terus belajar dan bertumbuh. Divisi Operasi adalah inti dari perusahaan yaitu energi bagi perusahaan. Tanpa adanya Divisi Operasi, maka perusahaan tidak akan mampu melakukan kegiatan utama. Divisi SDM menentukan alokasi tenaga kerja sehingga tenaga kerja tidak terbakar karena stres dan beban kerja. Masing-masing pekerja memiliki kualitas, pengetahuan dan juga keterbatasan. Sumber daya bagi Divisi Operasi dan Divisi SDM didapat dari Divisi Keuangan yang merupakan elemen kayu/ pohon. "Api" harus dikelola dengan baik untuk pengembangan dan sustainabilitas. Sesuai dengan sifat api yang memberikan panas, maka Divisi Operasi dan Divisi SDM juga memiliki sifat tersebut. Kayu menghasilkan api dan kayu akan terbakar saat menghasilkan api. Alokasi dana untuk Divisi Operasi dan Divisi SDM seharusnya dikelola dengan baik karena Divisi Keuangan tidak dapat terus-menerus menyuplai dana jika tidak terdapat pemasukan. Keuangan perusahaan akan berada dalam kondisi yang kritis jika api yaitu Divisi Operasi dan Divisi SDM menghabiskan dana terusmenerus tanpa memberikan keuntungan bagi perusahaan. Api yang berlebihan tanpa diimbangi dengan elemen lain dapat menyebabkan kebakaran di dalam perusahaan. Api yang berlebihan juga dapat meleburkan logam. Aktivitas dari Divisi Operasi yang berlebihan dapat membuat Divisi Riset dan Pengembangan dengan unsur logam bekerja keras untuk memenuhi kebutuhan Divisi Operasi, padahal inovasi yang dihasilkan oleh Divisi Riset dan Pengembangan tidak dapat ditentukan dengan pasti. Divisi Riset dan Pengembangan bisa menghasilkan banyak inovasi dan temuan dalam satu periode, tetapi riset yang dilakukan bisa tidak mendapatkan hasil yang baik pada periode lainnya. Jika logam dipaksa untuk berinovasi dengan target waktu, maka logam akan menjadi lebur dan tidak dapat berfungsi dengan baik. 


\section{Tanah}

Dasar dari pohon adalah di bawah yaitu pada tanah. Organisasi tumbuh berdasarkan fungsi dari Divisi Pemasaran. Pohon akan sangat menancap kuat pada tanah yang akan memberikan nutrisi untuk bertumbuh, sama seperti Divisi Keuangan yang mendapatkan suplai dari Divisi Pemasaran. Kinerja Divisi Pemasaran yang buruk akan berdampak pada sedikitnya dana yang dikelola oleh Divisi Keuangan. Divisi Pemasaran memiliki sifat tanah yaitu diplomatis, mudah berbaur, dan memperhatikan detail.

\section{Logam}

Proses pengolahan logam adalah salah satu dari inovasi besar dalam perkembangan hidup manusia. Logam merepresentasikan pengetahuan dan keahlian. Ada banyak jenis keahlian yang sama seperti logam yang memiliki banyak jenis untuk berbagai tujuan. Unsur logam direpresentasikan oleh Divisi Riset dan Pengembangan serta Divisi Sistem Informasi. Divisi tersebut dapat memanfaatkan pengetahuan divisi tersebut untuk menyelesaikan masalah dan menemukan inovasi terbaru bagi organisasi agar dapat berjalan dengan efektif. Logam juga bahan utama dari senjata. Hampir seluruh organisasi menggunakan inovasi dan pengetahuan sebagai senjata untuk berkompetisi saat ini. Divisi Riset dan Pengembangan serta Divisi Sistem Informasi memiliki sifat logam yaitu imajinatif, cerdas, dan haus terhadap ilmu.

\section{Air}

Air adalah elemen yang menggambarkan aliran kerja (workflow). Air selalu mengalir mengikuti jalur sama seperti Divisi Akuntansi yang memiliki standar pelaporan yang harus dipenuhi. Sesuai dengan sifat air, Divisi Akuntansi sangat terorganisasi, menyukai ketepatan/keakuratan, menyukai perintah, dan selalu bekerja sesuai dengan standar yang telah ditetapkan.

Gambaran mengenai hubungan saling mendukung di antara unit kerja/divisi sebagai Pusat Pertanggungjawaban dapat dilihat pada Gambar 1. Gambar tersebut menunjukkan arah transfer nilai yang dapat dijadikan sebagai dasar pembuatan KPI dalam evaluasi kinerja masing-masing divisi. Contohnya adalah KPI Divisi Operasi harus juga memperhitungkan nilai yang telah diberikan oleh Divisi Operasi kepada Divisi Pemasaran.

Yin Yang menjelaskan semua entitas dan peristiwa dalam hal interaksi antara dua sifat yang saling bergantung, Yin terkait dengan kegelapan, kepasifan, dan feminitas, sedangkan Yang terkait dengan cahaya, aktivitas dan maskulinitas (Wong, 1997). Wu Xing mengambil pendekatan yang serupa untuk memahami fenomena alam, tetapi mencakup gagasan bahwa "Lima Fase" (logam, kayu, air, api dan bumi) ada dalam proses siklus yang tidak pernah berakhir (Kommonen, 2011). Yin Yang dan $W u$ Xing yang seimbang dapat digambarkan sebagai organ internal manusia. Organ internal dihubungkan satu sama lain dalam satu sistem kontrol. Setiap organ internal mewakili elemen tertentu dalam model, sementara Yin Yang menggambarkan keseimbangan dan interaksi diantara elemen-elemen. Ketika salah satu organ internal berjalan terlalu hiperaktif, maka akan mengganggu operasi organ lain dalam sistem dan menyebabkan gangguan. Diagnosis yang tepat memerlukan pemeriksaan tubuh yang memberi tahu situasi sistem apakah dalam keadaan seimbang. Sama seperti tubuh manusia, kompetensi masing-masing divisi dalam organisasi juga harus sesuai porsi masingmasing.

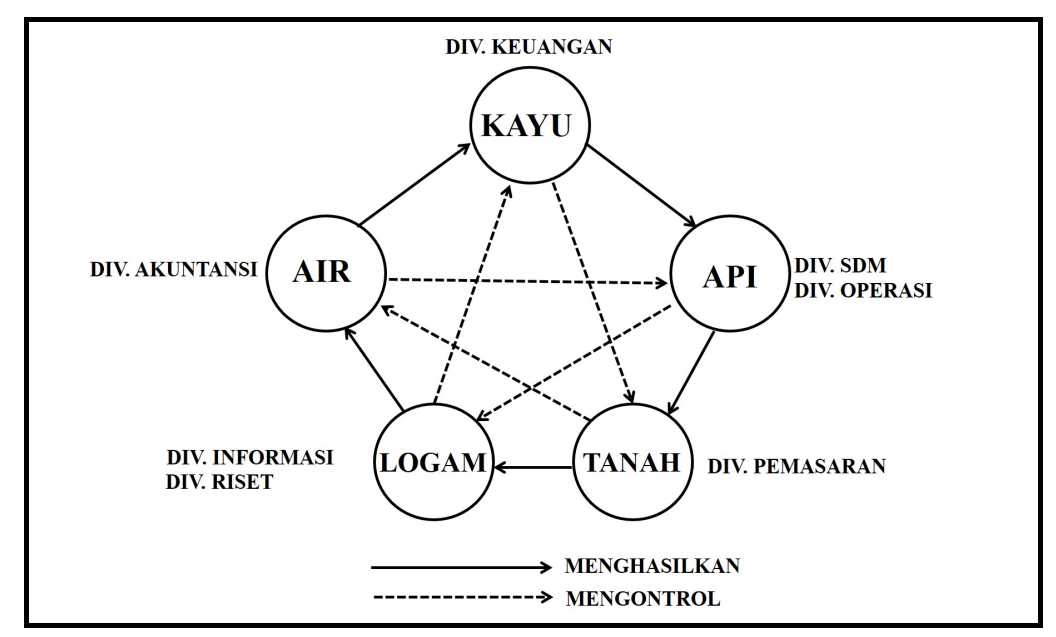

Gambar 1. Arah Transfer Nilai di Antara Unit Kerja/Divisi 
Dari filosofi Yin Yang; konsep penilaian kinerja pada pembentukan KPI diusulkan dalam penelitian ini untuk evaluasi kinerja Pusat Pertanggungjawaban yang seimbang dari segi "Individual" maupun segi "Persatuan". Dari filosofi Wu Xing, penelitian ini mengusulkan arah dari transfer nilai/ kerjasama masing-masing unit kerja/divisi.

\section{SIMPULAN}

Konsep Akuntansi Pertanggungjawaban dibuat dengan tujuan baik yaitu untuk memudahkan perusahaan dalam menilai kinerja masing-masing divisi serta untuk mengetahui divisi yang memiliki kelemahan dan memerlukan perbaikan. Namun, segala sesuatu di dunia ini memiliki sisi baik dan buruk pada saat yang bersamaan. Pusat Pertanggungjawaban memiliki sisi gelap yaitu dapat mendorong sifat egois dan individual di masing-masing divisi. Penelitian ini mencoba untuk mengusulkan konsep Akuntansi Pertanggungjawaban dengan perspektif keseimbangan yaitu Yin $Y a n g$ dan $W u$ Xing:

Dengan perspektif $Y$ in $Y a n g$ dan $W u$ Xing, divisi dalam perusahaan diharapkan menyadari bahwa kinerja sebuah divisi bukan karena usaha satu divisi tersebut tetapi karena bantuan dan manfaat yang diberikan divisi lain. Pada saat berproses mencapai kondisi sempurna, Pusat Pertanggungjawaban bukan lagi menjadi alat pemecah-belah, tetapi justru menjadi sumber inspirasi, pemersatu, dan pemberdaya setiap divisi dalam organisasi. Jika dapat menerapkan transfer nilai secara berkesinambungan dan konsisten, maka implementasi Akuntansi Pertanggungjawaban pada akhirnya dapat membangun empati antara divisi di dalam organisasi yang membawa organisasi menuju kepada keberlanjutan.

Penelitian ini masih bersifat konseptual dengan kerangka kerja dan pemaparan yang bertujuan untuk mempermudah praktisi mengadopsi pemikiran yang diajukan. Dengan kata lain, konsep Akuntansi Pertanggungjawaban yang dihasilkan dalam penelitian ini belum menyentuh aspek teknis. Oleh karena itu, penelitian selanjutnya diharapkan dapat membuat penilaian kinerja Pusat Pertanggungjawaban dengan Key Performance Indicator (KPI) yang memiliki indikator yang rinci beserta teknis pengukuran berdasarkan perspektif Yin Yang dan Wu Xing untuk masing-masing jenis divisi.

\section{DAFTAR RUJUKAN}

Cooper, J. C. (1981). Yin \& Yang: The Taoist Harmony of Opposites. 1st ed. Detroit: The Aquarian Press.

Evans, C., Gbadamosi, G., Wells, J., \& Scott, I. (2012). Balancing the Yin and Yang: The Role of Universities in Developing Softer Skills in Accountancy. Industry and Higher Education, 26(1), 63-70. doi:10.5367/ihe.2012.0081.

Hancock, P., Marriott, N., \& Duff, A. (2017). Research-teaching yin-yang? An empirical Study of Accounting and Finance Academics in Australia and New Zealand. Accounting and Finance, 59(1), 1-34. doi:10.1111/acfi.12257.

Hansen, D., Mowen, M., Heitger, D., Sands, J., Winata, L., \& Su, S. (2016). Managerial Accounting (Asia-Pacif). Boston: Cengage Learning.

Horngren, C. T., Datar, S. M., \& Rajan, M. V. (2012). Cost Accounting - A Managerial Emphasis (14th ed.). London: Pearson Education Limited.

Kommonen, K. (2011). Narratives on Chinese colour culture in business contexts: The Yin Yang Wu Xing of Chinese values. Cross Cultural Management: An International Journal, 8(3), 366-383. doi:101108/1352760111152879.

Law, K. M. Y. \& Kesti, M. (2014). Yin Yang and Organizational Performance. In Yin Yang and Organizational Performance: Five Elements for Improvement and Success. Springer-Verlag London. doi:10.1007/978-1-4471-6389-3.

Lee, H. J. \& Reade, C. (2018). The Role of Yin-Yang Leadership and Cosmopolitan Followership in Fostering Employee Commitment in China: A paradox Perspective. Cross Cultural and Strategic Management, 25(2), 276-298. doi:10.1108/CCSM-12-2016-0216.

Li,J., Wang, J., \& Fan, W. (2011). Yin yang and Company Growth: A Case Study of a Coal Company of Shanxi in China. Chinese Management Studies, 5(4), 380-393. doi:10.1108/17506141111183154. 
Merchant, K. A. \& Van der Stede, W. A. (2007). Management Control Systems: Performance Measurement, Evaluation and Incentives. 2nd ed. London: Pearson Education Limited.

Pauluzzo, R., Guarda, M., De Pretto, L., \& Fang, T. (2018). Managing Paradoxes, Dilemmas, and Change: A Case Study to Apply The Yin Yang Wisdom in Western Organizational Settings. Cross Cultural and Strategic Management, 25(2), 257-275. doi:10.1108/CCSM-08-2017-0094.

Robbins, S. P., \& Judge, T. A. (2013). Organisational Behavior (15th ed.). London: Pearson Education Limited.

Wong, E. (1997). Harmonizing Yin and Yang: The Dragon Tiger Classic. Colorado: Shambhala Publication. 